\title{
ПРИНЦИПИ ОРГАНІЗАЦЇ̈ МУЗЕЙНИХ ЗАНЯТЬ: ВІД ПРОСВІТНИЦТВА ТА ІДЕОЛОГІЇ - ДО ІНТЕРАКТИВНОСТІ ТА УНІВЕРСАЛЬНОСТІ
}

Світові тенденції розвитку освітньої галузі в сучасних умовах сприяють швидким та незворотнім змінам у сфері організації освітнього процесу. На перший план у конструюванні різних методик навчання виходять не відтворення інформації, а ії усвідомлення, можливість власної інтерпретації та конструювання нових знань, пошук різноманітних міждисциплінарних зв'язків. У зв'язку з цим набувають нового звучання думки про універсальність освітньої діяльності, зокрема, можливість забезпечувати навчальновиховний процес не лише у просторі школи, а в інституціях культури, чільне місце серед яких посідають музейні заклади.

Організація просвітницьких, навчальних, дослідницьких, проектних, навчальних, виховних, тренінгових, рекреаційних занять у просторі музею не лише є потужним важелем у процесі засвоєнні шкільної програми, організації неформальної освітньої діяльності, а й важливим чинником формування у молодого покоління власної картини світу - міждисциплінарної комбінації різних знань, умінь, навичок, зв'язків, переконань та ієрархії цінностей.

Мета нашого дослідження полягає у порівнянні історичних засад організаціі різноманітних занять у просторі музею та обгрунтуванні принципів сучасного музейного заняття як важливої складової освітнього процесу у середній та вищій школі. У викладі матеріалу ми будемо акцентувати увагу на загальноєвропейські тенденції розвитку музейної педагогіки, розглядаючи різні підходи, погляди, моделі, що узгоджується 3 вітчизняним досвідом у цій галузі знань.

Окремі аспекти порушеної проблематики, яка $є$ недостатньо вивченою у літературі, були предметом пошуків вітчизняних та зарубіжних науковців Є. Артемова, Т. Бєлофастової, Л. Гайди, М. Калонової, Ю. Ключко, В. Снагощенко, Б. Столярова, Л. Кетової, С. Михайличенко, Т. Мишевої, Ю. Павленко, М. Юхневич та ін.

Поставлена мета потребує різноманітної інтерпретації принципів навчання, які $є$ вихідними положеннями дидактики, розкривають зміст, організаційні форми і методи навчального процесу відповідно до загальної мети та законо- мірностей. Як зазначав С. Гончаренко, вітчизняна педагогічна наука розкриває систему дидактичних принципів, виходячи 3 наукового розуміння суті виховання й навчання [2, с. 270].

У контексті нашого дослідження важливо осягнути історичні контексти проведення музейних занять (занять у просторі музею) $з$ учнівською та студентською молоддю 3 метою навчання, виховання і розвитку. Фактично уперше такі заняття почали проводитися у Німеччині в XIX - на початку XX ст., коли і виникає сам термін «музейна педагогіка». Один 3 його авторів, Г. Фройденталь, розробив спеціальну методику роботи зі школярами, яка включала їх підготовку до відвідування музею й дальше закріплення одержаних знань та вражень за активної участі вчителя - учасника музейно-педагогічного процесу [5, с. 131].

Наприкінці XIX - початку XX ст. у європейській педагогічній думці формується уявлення про музей як освітній (просвітницький) центр, що співпрацює не лише зі школою, а й стає ланкою в єдиній системі позашкільної освіти. Відповідно, формується просвітницька модель музею, що відображає ставлення до нього як демократичної установи та просвітницького центру, здатного до реформування школи та єдиної системи позашкільної освіти [12, с. 14].

Таке розуміння музею зумовлювало організацію і проведення занять, які природно орієнтувалася на базові педагогічні принципи - наочності (адже музейні експозиції забезпечують чудову ілюстрацію будь-якого навчального матеріалу); доступності (оскільки будь-який матеріал, методично грамотно упорядкований та озвучений у музейному просторі оптимально сприймається усіма рецепторами людини); урахування вікових та індивідуальних особливостей розвитку особистості (позаяк адаптований експозиційний матеріал сприяє глибокому усвідомленню та запам'ятовуванню потрібної й важливої інформації).

Реалізація останнього принципу часто була доволі складним завданням для педагогів, адже і в сучасних умовах доволі важко підготувати міждисциплінарне адаптоване заняття для певної вікової групи. 
У 20-50-х рр. ХХ ст. музей починає розглядатися як «потужна зброя політичної та просвітницької роботи», що зумовлює розширення форм його роботи та водночас звужує зміст діяльності [12, с. 15]. Вищезазначена суперечність виявила ідеологічний контекст музейної педагогіки, який найбільш яскраво виявив себе на практиці у Німеччині та СРСР у 20-30-х рр. XX ст. Подібні тенденції можна відзначити й на теренах України, - показовим, наприклад, $є$ створення громадської організації «Войовничий матеріаліст», метою якої був контроль діяльності музеїв і сприяння комуністичному вихованню працівників [8, с. 219].

Діяльність музеїв набуває масового характеру, сприяє залученню великої кількості людей для ознайомлення 3 пізнавальною інформацією, історичними образами різних епох, науковими фактами у форматі навчальної екскурсії, проте часто включає ідеологічну обробку, «промивання мізків», формування чорно-білого мислення тощо. У такий спосіб визначальними засадами музейної діяльності, поряд із наочністю та доступністю, стають:

- принцип ідеологічної спрямованості матеріалу навчання (який шляхом переконання формує засади бажаної поведінки та реакції на певні дії), забезпечуючи ефективну роботу тоталітарної системи);

- принцип зв'язку навчання 3 життям на матеріалах експозиції (що набуває неоднозначного змісту в умовах порівняння «ганебного минулого» та «активної боротьби» за «світле майбутнє»);

- принцип активності (коли ідеологічний вплив на експозиції спричиняв зміни у психіці та свідомості вихованців, створюючи ілюзорні уявлення щодо навколишніх суспільних процесів).

У 60-80-х pp. XX ст. під впливом суспільнополітичних змін відбувається пошук нових засад для організація музейних занять, що зумовлюе утвердження інформативної моделі, що розглядає музей як засіб поширення знань та науковопросвітницьку роботу [12, с. 15].

Відзначимо, що цей період у країнах Західної Європи та США називають ще «ерою музейного буму», коли велика кількість людей починає масово відвідувати музейні заклади у пошуках не лише цікавої інформації, а й можливості осягнути свою історію та культуру.

Відтак, на перший план виходять:

- принцип науковості (який наголошуе на автентичності, справжності, важливості музейних предметів як невичерпного джерела знань $з$ історії та культури);

- принцип інформативності (що уможливлює включення в освітній процес у просторі музею значної кількості цікавої та пізнавальної інформації);

- принцип масовості (передбачає залучення значної кількості відвідувачів для ознайомлення з експозиційними матеріалами).

У процесі розвитку комунікативної моделі (кінець 1980-х - початок 2000-х рр.), яка наголошувала на ставленні до відвідувача як до суб'єкта музейно-освітньої діяльності, носія певних культурних установок та формуванні ціннісного ставлення до історико-культурної спадщини $[12$, с. $15-16)$, визначальними стають:

- принцип комунікативності (що дозволяв будувати навчальні заняття 3 урахуванням пізнавальної активності відвідувачів та їх тісної взаємодії);

- принцип зворотного зв'язку (який ураховував особливості художнього сприйняття відвідувачами експозиції, зокрема, їх рефлексії, оцінки та судження);

- принцип послідовності (передбачае певну ієрархію завдань, логіку й упорядкованість у поданні матеріалу, що вкрай важливо для створення довгострокових музейно-педагогічних програм).

Зауважимо, що кожна з наведених моделей у певний спосіб об'єднує поняття «музейна педагогіка», «музейна комунікація», «педагогічна діяльність музеїв», що зумовлює актуалізацію принципу інтегративності (у сенсі об'єднання змістової складової музейних предметів на перетині історії, культури, естетики та мистецтва).

Це підтверджується ототожненням музею, як зазначала словацька дослідниця А. Грегорова, 3 різними можливостями його функціонального призначення у контексті організації та проведення занять - музей-склад, музей-сейф, музейпаноптикум, музей-шкільний кабінет, музей-осередок досліднииького матеріалу, музей-клуб, музей-салон, шкільний музей, музей-скансен [14, с. 60-68].

Зазначене узгоджується із визначеннями можливих образів музею як педагогічної системи, запропонованих С. Троянською - музеи пам'ять; музеи - виставка; музей - школа, підручник; музей - кунсткамера; музей - атмосфера, дух, середовище; музей - театр; музей - санаторій $[11$, c. 51].

Перелік цих образів може бути продовжений, проте для кожного з них у різний спосіб можна обгрунтувати певний дидактичний принцип, який матиме визначальне значення у розкритті змісту й характеру відповідного музейного заняття крізь призму музейної дидактики. Наприклад, у конструкції «музей-пам'ять» доречним буде звернення до принцииу спадкоємності (адже музей здатний моделювати будьякий відрізок простору і момент часу, руйнуючи «кордони просторово-часової локалізованості людського досвіду») [7], натомість у варіанті «му- 
зей-театр» важливими є принциипи емоційності та смислової й емоційної єдності (що гармонійно регулюють обсяг, характер та спосіб комунікації в музеї з їі емоційно-чуттєвим змістом та відповідним сприйняттям).

Дослідники виокремлюють низку характеристик музейно-педагогічної діяльності, які фактично можна ототожнити 3 принципами. Зокрема, мова йде про принципи, які ототожнюються 3 властивостями музейного предмета, - інформативності, комунікативності та атрактивності [11, c. 31], характерні для організації повноцінних музейних занять в умовах взаємодії музеїв із закладами освіти та різними групами відвідувачів [3, с. 43-44].

На думку науковців, аналіз різних визначень та інтерпретацій музейної педагогіки дозволяє виокремити в їі змісті декілька аспектів. Серед них найбільш значущими аспектами можуть бути наступні: практична культурно-освітня діяльність музею, реалізація різних посередницьких та освітніх завдань, пов' язаних з обслуговуванням відвідувачів (виставкові проекти, інформаційне забезпечення, екскурсії, творчі майстерні); удосконалення методології та методики реалізації освітньої функції музею щодо до різних категорій відвідувачів; наукові дослідження принципів комунікативної політики музеїв [6, с. 288; 9, c. 313].

Сучасний розвиток освіти в епоху інформаційних технологій та його відображення у музейній справі дає підстави виокремити ще одну ключову модель - модель «participatory museum» (музей співучасті), яку ще називають «новим рівнем музейної інтерактивності» [4, с. 38-40].

Зазначена модель викликає неабиякий інтерес, адже $\epsilon$ «своєрідним символом сучасної епохи» у сенсі застосування технологій Web 2.0, що уможливлює створення віртуальних музеїв [6, с. 60-64], проектування занять у музейному середовищі $з$ урахуванням індивідуальних потреб та запитів кожного конкретного відвідувача iз включенням персонального середовища навчання (особистих файлів, сторінок у соціальних мережах, відео, блогів тощо).

Таким чином, модель «participatory museum» побудована на засадах принципово нових, сучасних дидактичних принципів організації музейного заняття, зокрема:

- партисипації (відкритості назовні та до інших людей, спільної участі у створенні різноманітного музейного контенту);

- інклюзіï (сприймання, відчуття та включення різних людей до доступного освітнього середовища);

- інтерактивності (організації спільної діяльності на експозиції музею, яка у такому форматі набуває принципово нових ознак та харак- теристик);

- креативності (включення відвідувача у процес пошуку й осягнення музейної інформації та ііі творчого застосування);

- універсальності (чіткого механізму роботи з можливістю залучення до співпраці відвідувачів усіх вікових категорій);

- віртуалізації (застосування віртуального простору, «доповнюючої реальності» та інших сучасних медіа технологій);

- мультикультурності (заохочення до співпраці людей будь-якого національного, етнічного та мовного походження).

Зазначені принципи відповідають сучасним вимогам до проектування, організації та практичного втілення занять у просторі музею, що розробляються вітчизняними авторами Ю. Ключко, Ю. Павленко, І. Пантелейчук, О. Харченко та ін.

За своїм змістом вони узгоджуються із зарубіжними аналогами. Наприклад, в інтерпретації Американської Асоціації музеїв вони спрямовані на участь у спільноті та служіння музейній аудиторії; адресність та організація різноманітних перспективних занять; досконалість у змісті пропонованих знань; втілення навчальних досліджень у музейну практику; застосування різних освітніх інструментів для сприяння навчанню у музейному просторі; сприяння освіті як центральній місії музею; проектування реальних изілеи та розробка стратегій їх досягнення; сприяння професійному розвитку, відкритість для нових ідей та підходів; вплив суспільної політики на підтримку навчання в музеї [13].

Чимало наведених принципів дозволяють ототожнювати музейну педагогіку з технологією навчання, що значно розширює ії потенціал та можливості щодо проектування якісно нових музейних занять для різновікової аудиторії.

Отже, співставлення різних підходів щодо визначення оптимальних принципів музейного заняття дає підстави стверджувати, що музей повинен стати відкритим для відвідувача, партнерів та потенційних клієнтів, які потребують використання музейних артефактів, а також орієнтуватися на запити зовнішніх споживачів послуг з урахуванням своїх інтересів, стати конкурентоздатним у сфері культури та соціального розвитку $[1$, с. 38].

Проведений ретроспективний аналіз встановлює певну еволюцію й трансформацію принципів організації музейного заняття - від його просвітницької та ідеологічної місії до інтерактивності та універсальності як важливих всеохоплюючих характеристик сучасного «суспільства знань», побудованого на засадах гуманізму, міжособистісної комунікації, рівності прав та можливостей кожної людини. 


\section{СПИСОК ВИКОРИСТАНИХ ДЖЕРЕЛ}

1. Гиль А.Ю. Эволюция музея в контексте становления информационного общества. Вестник Томского государственного универсиmema. 2008. № 306. С. 35-38.

2. Гончаренко С. Український педагогічний словник / гол. ред. С. Головко. Київ: Либідь, 1997. 373 c.

3. Ключко Ю. М. Місія сучасного музею у контексті освітніх проблем. Культура і мистецтво у сучасному світі. 2014. Вип. 15. С. 43-48.

4. Лещенко A. Participatory Museum: новый уровень музейной интерактивности. Музей. 2011. № 3. C. 38-40.

5. Мышева Т.П. Становление музея и музейной педагогики. Вестник Таганрогского института имени А. П. Чехова. 2006. № 2. C. 129-133.

6. Пантелейчук I. В. Віртуальний музей. Питання культурологіі. Київ, 2002. Вип. 18. C. 60-64.

7. Пшеничная С. В. «Музейный язык» и феномен музея. Серия «Мыслители»: В диапазоне гуманитарного знания. Вып. 4: Сборник к 80летию профессора М. С. Кагана. СанктПитербург: Санкт-Петербургское философское общество, 2001. С. 233. URL: http:// anthropology.ru/ru/text/pshenichnayasv/muzeynyy-yazyk-i-fenomen-muzeya

8. Савчук В. Музеї України як центри краєзнавчої роботи в 20-х - 30-х рр. ХХ ст. Kраєзнавство. 2011. № 2. С. 216-222.

9. Снагощенко В. Еволюція концептуальних моделей сучасного музею. Світогляд - Філософія - Релігія. 2013. Вип. 4. С. 306-315.

10. Тимофеева Л. С. Музейная педагогика или педагогика музея: формирование понятийно-категориального аппарата. Филология $u$ культура. 2012. № 2. С. 287-291.

11. Троянская С. Л. Музейная педагогика и ее образовательные возможности в развитии общекультурной компетентности: учебное пособие. Ижевск: Научная книга, 2007. 138 с.

12. Юхневич М. Ю. Я поведу тебя в музей. Учебное пособие по музейной педагогике: монография. Москва, 2001. 223 с.

13. Excellence in Practice: Museum Education Principles and Standards. American Association of Museums, 2002. URL: http://ww2.aamus.org/docs/default-source/accreditation/ committee-on-education.pdf?sfvrsn $=0$

14. Gregorová A. Múzeá a múzejníctvo. Martin: Matica slovenská, 1984. 303 s.

\section{REFERENCES}

1. Gil', A. Ju. (2008). Jevoljucija muzeja v kontekste stanovlenija informacionnogo obshhestva. Vestnik Tomskogo gosudarstvennogo universiteta, 306, 35-38 [in Russian].

2. Honcharenko, S. (1997). Ukrainskyi pedahohichnyi slovnyk. S. Holovko (Ed.). Kyiv: Lybid [in Ukrainian].

3. Kliuchko, Yu. M. (2014). Misiia suchasnoho muzeiu u konteksti osvitnikh problem. Kultura $i$ mystetstvo u suchasnomu sviti, Issue 15, 43-48 [in Ukrainian]

4. Leshhenko, A. (2011). Participatory Museum: novyj uroven' muzejnoj interaktivnosti. Muzej, 3, 38-40 [in Russian].

5. Mysheva, T.P. (2006). Stanovlenie muzeja i muzejnoj pedagogiki. Vestnik Taganrogskogo instituta imeni A. P. Chehova, 2, 129-133 [in Russian].

6. Panteleichuk, I. V. (2002). Virtualnyi muzei. Pytannia kulturolohii. Kyiv, Issue 18, 60-64 [in Ukrainian].

7. Pshenichnaja, S. V. (2001). «Muzejnyj jazyk» i fenomen muzeja. Serija "Mysliteli»: $V$ diapazone gumanitarnogo znanija. Issue 4: Sbornik k 80-letiju professora M. S. Kagana. Sankt-Piterburg: Sankt-Peterburgskoe filosofskoe obshhestvo, 233. URL: http://anthropology.ru/ru/text/ pshenichnaya-sv/muzeynyy-yazyk-i-fenomenmuzeya [in Russian].

8. Savchuk, V. (2011). Muzei Ukrainy yak tsentry kraieznavchoi roboty v 20-kh - 30-kh rr. XX st. Kraieznavstvo, 2, 216-222 [in Ukrainian].

9. Snahoshchenko, V. (2013). Evoliutsiia kontseptualnykh modelei suchasnoho muzeiu. Svitohliad - Filosofiia - Relihiia, Issue 4, 306-315 [in Ukrainian].

10. Timofeeva, L. S. (2012). Muzejnaja pedagogika ili pedagogika muzeja: formirovanie ponjatijnokategorial'nogo apparata. Filologija i kul'tura, 2, 287-291 [in Russian].

11. Trojanskaja, S. L. (2007). Muzejnaja pedagogika $\mathrm{i}$ ee obrazovatel'nye vozmozhnosti $\mathrm{v}$ razvitii obshhekul'turnoj kompetentnosti. Izhevsk: Nauchnaja kniga [in Russian].

12. Juhnevich, M. Ju. (2001). Ja povedu tebja $\mathrm{v}$ muzej. Uchebnoe posobie po muzejnoj pedagogike. Moskva [in Russian].

13. Excellence in Practice: Museum Education Principles and Standards. (2002). American Association of Museums, URL: http://ww2.aamus.org/docs/default-source/accreditation/ committee-on-education.pdf?sfvrsn=0

14. Gregorová, A. (1984). Múzeá a múzejníctvo. Martin: Matica slovenská. 